\title{
PENDIDIKAN POLITIK BAGI PEMILIH MENJELANG PEMILU SERENTAK 2019
}

\author{
Anang Dony Irawan \\ Fakultas Hukum Universitas Muhammadiyah Surabaya \\ e-mail: anank_afni@yahoo.co.id
}

\begin{abstract}
Abstrac
The existence of the Constitutional Court Decision Number 14 / PUU-XI / 2013 in the trial case of Law Number 42 Year 2008 concerning General Elections of the President and Vice President whose decisions are final states that the holding of the 2019 General Elections and the subsequent General Elections shall be held simultaneously. The idea of holding a simultaneous General Election in 2019 certainly had a political impact, both nationally and regionally. The ruling of the Constitutional Court gave birth to Law Number 7 of 2017 concerning General Elections. This has had a huge impact and challenge for the Indonesian people in improving the electoral system and implementing a better democracy. The purpose of this study is to find out how to realize political education for voters ahead of the 2019 simultaneous elections. This study is a juridical normative approach to legislation. From the results of the study there is a legal vacuum that requires the General Election Commission to conduct Socialization, Voter Education, and Community Participation in the 2019 Election. In the Regional Head Election process there are technical rules governing the Socialization, Voter Education, and Community Participation, but do not include the threat of sanctions if it does not carry out the said activity. The resulting conclusion is that political education for voters ahead of the 2019 concurrent elections is very important to carry out, as an effort to realize the Sovereignty of a Strong State. The resulting recommendation is to make a legal rule regarding the obligation to carry out political education for voters ahead of the 2019 simultaneous elections as an effort to realize the Strong Sovereign State Voters in the 2019 Election along with the threat of sanctions for election administrators in an Act.
\end{abstract}

Keywords: 2019 Election, Voter Education, Strong Sovereign State Voters.

\section{PENDAHULUAN}

Pemilihan Umum yang biasa disebut Pemilu merupakan bagian dari proses perwujudan bagi negara yang menganut sistem demokrasi. Proses penyelenggaraan pemilu dimulai dari persiapan, pelaksanaan, dan pelaporan. Partisipasi masyarakat dalam Pemilu sangatlah diperlukan, mengingat masyarakat mempunyai hak pilih yang 
tidak bisa diwakilkan kepada orang lain. Hak pilih diberikan kepada setiap warganegara yang dijamin oleh Undang-Undang. Hak ini merupakan hak konstitusional setiap warganegara yang telah memenuhi syarat untuk kemudian namanya masuk dalam Daftar Pemilih. Dari data pemilih yang akurat dan berkualitas inilah diharapkan bisa terwujud Pemilu 2019 yang Pemilih Berdaulat Negara Kuat.

Pemilihan Umum merupakan salah satu sendi untuk tegaknya sistem politik demokrasi. Oleh karena itu tujuan dari adanya pemilihan umum adalah untuk mengimplementasikan prinsip-prinsip demokrasi dengan cara memilih wakil rakyat di Badan Perwakilan Rakyat, dalam rangka mengikutsertakan rakyat dalam kehidupan ketatanegaraan. ${ }^{1}$

Fakta menunjukkan bahwa untuk penetapan perolehan jumlah kursi Calon Anggota Legislatif dan pasangan Calon Presiden dan Calon Wakil Presiden ditentukan berdasarkan banyaknya suara sah dari warganegara yang terdaftar sebagai pemilih. Suara sah didapatkan dari jumlah pemilih yang menggunakan hak pilihnya dengan benar pada saat hari pemungutan suara dilaksanakan. Namun tidak menutup kemungkinan juga ada pemilih yang tidak mennggunakan hak plihnya secara benar atau bahkan tidak menggunakan hak pilihnya, dengan kata lain tidak hadir di Tempat Pemungutan Suara walaupun namanya sudah ada di Daftar Pemilih Tetap.

Bila data kependudukan tidak akurat, maka bisa terjadi tidak akurat pula data pemilih dalam Pemilu 2019. Bila hal ini terjadi, bisa jadi ada indikasi akan lemahnya sistem administrasi kependudukan Pemerintah. Tidak menutup kemungkinan bisa terjadi kegaduhan dalam proses penyelenggaraan Pemilu 2019 yang adil dan berintegritas. Proses demokrasi akan terancam dengan data pemilih yang tidak akurat. Maka diperlukan adanya pemutakhiran data pemilih. Pemutakhiran Data Pemilih merupakan kegiatan untuk memperbaharui data pemilih berdasarkan Daftar Pemilih Tetap dari Pemilu atau Pemilihan Terakhir dan mempertimbangkan DP4 dengan cara melakukan verifikasi secara faktual data pemilih dan selanjutnya digunakan sebagai bahan penyusunan DPS yang dilaksanakan oleh KPU/KIP Kabupaten/Kota dengan dibantu PPK dan PPS. ${ }^{2}$ Pemutakhiran data pemilih dilakukan setelah adanya Daftar Penduduk Potensial Pemilih Pemilihan (DP4). DP4 adalah data yang disediakan oleh Pemerintah berisikan data penduduk yang memenuhi persyaratan sebagai Pemilih pada saat Pemilihan diselenggarakan. ${ }^{3}$

Selain itu diperlukan juga pendidikan pemilih menjelang Pemilu serentak 2019. Hal ini bertujuan agar setiap warganegara yang memiliki hak pilih secara sadar dan senang hati untuk datang ke Tempat Pemungutan Suara menggunakan hak pilihnya secara tepat dan benar. Karena apabila pemilih sudah berdaulat dalam menggunakan hak pilihnya, maka dengan harapan bisa membuat bangsa ini menjadi kuat.

1 Heru Cipto Handoyo, Hukum Tata Negara, Kewarganegaraan Dan Hak Asasi Manusia, Universitas Atmajaya, Jakarta, 2003, hal. 208.

2 Peraturan Komisi Pemilihan Umum Republik Indonesia Nomor 2 Tahun 2017 tentang Pemutakhiran Data dan Penyusunan Data Pemilih Dalam Pemilihan Gubernur dan Wakil Gubernur, Bupati dan Wakil Bupati, dan/atau Walikota dan Wakil Walikota Pasal 1 angka 23.

${ }^{3}$ Ibid, Pasal. 1 angka 19. 


\section{METODE PENELITIAN}

Dalam penelitian ini saya menggunakan pendekatan undang-undang (statute approach), yaitu menelaah semua undang-undang yang berkaitan dengan isu hukum yang akan dibahas disini. Selain itu, referensi dari beberapa buku yang dapat menunjang penulisan ini juga saya gunakan. Pada dasarnya penulisan ini menggunakan penelitian secara yuridis normatif atau sesuai dengan peraturan perundang-undangan yang berlaku di Indonesia.

\section{HASIL DAN PEMBAHASAN}

Sesuai amanat konstitusi Negara Kesatuan Republik Indonesia Pasal 22E tentang Pemilihan Umum untuk memilih anggota Dewan Perwakilan Rakyat, Dewan Perwakilan Daerah, Presiden dan Wakil Presiden, dan Dewan Perwakilan Rakyat Daerah yang diselenggarakan setiap lima tahun sekali. ${ }^{4}$

Pemilihan Umum yang selanjutnya disebut Pemilu adalah sarana kedaulatan rakyat untuk memilih anggota Dewan Perwakilan Rakyat, anggota Dewan Perwakilan Daerah, Presiden dan Wakil Presiden, dan untuk memilih anggota Dewan Perwakilan Rakyat Daerah, yang dilaksanakan secara langsung, umum, bebas, rahasia, jujur, dan adil dalam Negara Kesatuan Republik Indonesia berdasarkan Pancasila dan UndangUndang Dasar Negara Republik Indonesia Tahun 1945. ${ }^{5}$

Indonesia melakukan proses demokrasi Pemilu untuk pertama kalinya setelah merdeka pada tahun 1955 sebagai wujud kedaulatan rakyat yang berdasarkan Pancasila dan UUD 1945. Pemilu berfungsi sebagai alat penyaring bagi "politikus-politikus" yang akan mewakili dan membawa suara rakyat di dalam lembaga perwakilan. Mereka yang terpilih dianggap sebagai orang atau kelompok yang mempunyai kemampuan atau kewajiban untuk bicara dan bertindak atas nama suatu kelompok yang lebih besar melalui partai politik (parpol). ${ }^{6}$

Macam pemilu secara teori ada 2, yaitu pemilihan secara langsung dan tidak langsung. Dalam hal pemilihan secara tidak langsung, pemilihan pemimpin melalui orang atau lembaga yang berwenang. Sebelum tahun 2004, untuk pemilihan pemimpin dilakukan oleh Legislatif. Lembaga Tertinggi Negara, MPR yang terdiri dari anggota DPR, Utusan Golongan, Utusan Daerah, dan Utusan ABRI melaksanakan pemilihan Presiden dan Wakil Presiden. Di daerah untuk pemilihan Gubernur, Bupati dan Walikota dilakukan oleh DPRD.

Dalam pemilihan langsung masyarakat yang memiliki hak pilih diberi

${ }^{4}$ Undang-Undang Dasar Republik Indonesia 1945 Hasil Amandemen, Asa Mandiri, Jakarta, 2006, hal. 17.

5 Undang-Undang Republik Indonesia Nomor 7 Tahun 2017 Tentang Pemilihan Umum, Citra Umbara, Bandung, 2017, hal. 3.

${ }^{6}$ Moh. Mahfud MD, Politik Hukum di Indonesia, Rajawali Pers, Jakarta, Ed. Revisi, Cet. 4, 2011, hal. 60 . 
kesempatan secara langsung untuk menentukan pemimpin pilihannya. Proses pemilihan inilah yang dianggap oleh sebagian masyarakat sekarang sebagai proses pemilihan yang mencerminkan demokrasi. Kedaulatan rakyat diartikan sebagai kekuasaan tertinggi yang memberikan legitimasi terhadap negara dalam menerapkan dan menjalankan kebijakan (policy). ${ }^{7}$

Pemilu di Indonesia diselenggarakan oleh suatu Komisi Pemilihan Umum yang bersifat nasional, tetap dan mandiri. KPU bersama-sama dengan Badan Pengawas Pemilu (Bawaslu) dan Dewan Kehormatan Penyelenggara Pemilu (DKPP) merupakan satu kesatuan fungsi penyelenggaraan pemilu yang memilih anggota Dewan Perwakilan Rakyat, anggota Dewan Perwakilan Daerah, Presiden dan Wakil Presiden, dan untuk memilih anggota Dewan Perwakilan Rakyat Daerah secara langsung oleh rakyat.

Tugas KPU sebagaimana diatur dalam Pasal 12 Undang-Undang Nomor 7 Tahun 2017 diantaranya :

a. merencanakan program dan anggaran serta menetapkan jadwal;merryusun tata kerja KPU, KPU Provinsi, KPU Kabupaten/Kota, PPK, PPS, KPPS, PPLN, dan KPPSLN;

b. menyusun Peraturan KPU untuk setiap tahapan Pemilu;

c. mengoordinasikan, menyelenggarakan, mengendalikan, dan memantau semua tahapan pemilu;

d. menerima daftar pemilih dari KPU Provinsi;

e. memutakhirkan data pemilih berdasarkan data pemilu terakhir dengan memperhatikan data kependudukan yang disiapkan dan diserahkan oleh Pemerintah dan menetapkannya sebagai daftar pemilih;

f. membuat berita acara dan sertifikat rekapitulasi penghitungan hasil suara serta wajib menyerahkannya kepada saksi Peserta Pemilu dan Bawalu;

g. mengumumkan calon anggota DPR, calon anggota DPD, dan Pasangan Calon terpilih serta membuat berita acaranya;

h. menindaklanjuti dengan segera putusan Bawaslu atas temuan dan laporan adanya dugaan pelanggaran atau sengketa Pemilu;

i. menyosialisasikan penyelenggaraan pemilu dan/atau yang berkaitan dengan tugas dan wewenang KPU kepada masyarakat;

j. melakukan evaluasi dan membuat laporan setiap tahapan Penyelenggaraan pemilu; dan

k. melaksanakan tugas lain dalam penyelenggaraan pemilu sesuai dengan ketentuan peraturan perundang-undangan.

Wewenang KPU diatur dalam Pasal 13 Undang-Undang Nomor 7 Tahun 2017 diantaranya :

a. menetapkan tata kerja KPU, KPU Provinsi, KPU Kabupaten/Kota, PPK, PPS, KPPS, PPLN, dan KPPSLN;

b. menetapkan Peraturan KPU untuk setiap tahapan pemilu;

${ }^{7}$ I Dewa Gede Atmadja, dkk, Teori Konstitusi \& Konsep Negara Hukum, Setara Press, Malang, 2015, hal. 90 . 
c. menetapkan peserta pemilu;

d. menetapkan dan mengumumkan hasil rekapitulasi penghitungan suara tingkat nasional berdasarkan hasil rekapitulasi penghitungan suara di KPU Provinsi untuk Pemilu Presiden dan Wakil Presiden dan untuk pemilu anggota DPR serta hasil rekapitulasi penghitungan suara di setiap KPU Provinsi untuk pemilu anggota DPD dengan membuat berita acara penghitungan suara dan sertifikat penghitungan suara;

e. menerbitkan keputusan KPU untuk mengesahkan hasil Pemilu dan mengumurnkannya;

f. menetapkan dan mengumumkan perolehan jumlah kursi anggota DPR, anggota DPRD Provinsi, dan anggota DPRD Kabupaten/Kota untuk setiap partai politik peserta pemilu anggota DPR, anggota DPRD Provinsi, dan anggota DPRD Kabupaten/Kota;

g. menetapkan standar serta kebutuhan pengadaan dan pendistribusian perlengkapan;

h. membentuk KPU Provinsi, KPU Kabupaten/Kota, dan PPLN;

i. mengangkat, membina, dan memberhentikan anggota KPU Provinsi, anggota KPU Kabupaten/Kota, dan anggota PPLN;

j. menjatuhkan sanksi administratif dan/atau menonaktifkan sementara anggota KPU Provinsi, anggota KPU Kabupaten/Kota, anggota PPLN, anggota KPPSLN, dan Sekretaris Jenderal KPU yang terbukti melakukan tindakan yang mengakibatkan terganggunya tahapan penyelenggaraan Pemilu yang sedang berlangsung berdasarkan putusan Bawaslu dan/atau ketentuan peraturan perundang-undangan;

k. menetapkan kantor akuntan publik untuk mengaudit dana kampanye Pemilu dan mengumumkan laporan sumbangan dana Kampanye Pemilu; dan

1. melaksanakan wewenang lain dalam penyelenggaraan Pemilu sesuai dengan ketentuan peraturan perundang-undangan.

Pasal 13 Undang-Undang Nomor 7 Tahun 2017 mengatur tentang Kewajiban KPU, yaitu :

a. melaksanakan semua tahapan penyelenggaraan pemilu secara tepat waktu;

b. memperlakukan Peserta pemilu secara adil dan setara;

c. menyampaikan semua informasi penyelenggaraan pemilu kepada masyarakat;

d. melaporkan pertanggungjawaban penggunaan anggaran sesuai dengan ketentuan peraturan perundang-undangan;

e. mengelola, memelihara, dan merawat arsip/dokumen serta melaksanakan penyusutannya berdasarkan jadwal retensi arsip yang disusun oleh KPU dan lembaga Pemerintah yang menyelenggarakan urusan arsip nasional atau yang disebut dengan nama Arsip Nasional Republik Indonesia;

f. mengelola barang inventaris KPU sesuai dengan ketentuan peraturan perundangundangan; 
g. menyampaikan laporan periodik mengenai Penyelenggaraan Pemilu kepada Presiden dan DPR dengan tembusan kepada Bawaslu;

h. membuat berita acara pada setiap rapat pleno ditandatangani oleh ketua dan anggota KPU;

i. menyampaikan laporan Penyelenggaraan Pemilu kepada Presiden dan DPR dengan tembusan kepada Bawaslu paling lambat 30 (tiga puluh) hari setelah pengucapan sumpah/janji pejabat;

j. melaksanakan putusan Bawaslu mengenai sanksi atas pelanggaran administratif dan sengketa proses pemilu;

k. menyediakan data hasil Pemilu secara nasional;

1. melakukan pemutakhiran dan memelihara data pemilih secara berkelanjutan dengan memperhatikan data kependudukan sesuai ketentuan peraturan perundang-undangan;

m. melaksanakan putusan DKPP; dan

n. melaksanakan kewajiban lain sesuai dengan ketentuan peraturan perundangundangan.

Setiap pelaksanaan pemilu dilaksanakan berdasarkan asas langsung, umum, bebas, rahasia, jujur, dan adil. Hal ini dimaksudkan untuk memenuhi prinsip-prinsip penyelenggarannya yang mandiri, jujur, adil, berkepastian hukum, tertib, terbuka, proporsional, profesional, akuntabel, efektif, dan efisien. Dengan harapan Pemilu 2019 menjadi pemilu yang menempatkan Pemilih Berdaulat Negara Kuat, adil dan berintegritas. Adil yang berarti merata dan tidak memihak. Berintegritas dalam melaksanakan setiap tahapan penyelenggaraan pemilu, taat asas, dan taat aturan.

Untuk menyokong keberhasilan penyelenggaraan pemilu 2019, maka diperlukan data pemilih yang akurat dengan pendidikan politik bagi pemilih. Tahapan ini seringkali menjadi tolak ukur akan keberhasilan penyelenggaraan pemilu maupun untuk penghitungan jumlah suara yang harus diperoleh untuk bisa menjadi anggota legislatif maupun Presiden dan Wakil Presiden, termasuk jumlah kursi bagi partai politik. KPU hanya bisa menerima data pemilih dari data kependudukan yang diperoleh dari Pemerintah.

Pemutakhiran data pemilih sangat penting sebagai upaya mewujudkan pemilu 2019 yang adil dan berintegritas. Hal ini bisa dilihat atas amanat Undang-Undang yang mewajibkan KPU dan KPU Kabupaten/Kota dalam memelihara dan memutakhirkan data pemilih yang dapat terintegrasi dengan sistem administrasi kependudukan. Dapat dilihat disini bahwa data kependudukan yang diperoleh dari Pemerintah dan Pemerintah Daerah haruslah data yang akurat sebagai acuan untuk menghasilkan daftar pemilih yang akurat pula. Disinilah diperlukan pendidikan politik kepada pemilih untuk juga aktif dalam tahapan penyelenggaraan pemilu serentak 2019.

Apalagi dengan adanya Putusan Mahkamah Konstitusi Nomor 14/PUU-XI/2013 dalam perkara pengujian Undang-Undang Nomor 42 Tahun 2008 Tentang Pemilihan Umum Presiden dan Wakil Presiden yang putusannya bersifat final menyatakan bahwa penyelenggaraan Pemilihan Umum tahun 2019 dan Pemilihan Umum seterusnya 
dilaksanakan secara serentak. Ide penyelenggaraan Pemilihan Umum serentak tahun 2019 tentu membawa dampak politik, baik secara nasional maupun daerah.

Putusan Mahkamah Konstitusi itu telah melahirkan Undang-Undang Nomor 7 Tahun 2017 tentang Pemilihan Umum. Hal ini membawa dampak dan tantangan yang besar bagi bangsa Indonesia dalam memperbaiki sistem pemilu dan penerapan demokrasi yang lebih baik. Pemilihan Umum untuk memilih Calon Anggota Legislatif dan Pasangan Calon Presiden dan Calon Wakil Presiden dilaksanakan secara serentak di tahun 2019. Sudah tentu surat suara yang digunakan bertambah.

Pendidikan politik merupakan usaha yang sadar untuk mengubah proses sosialisasi politik masyarakat sehingga mereka memahami dan benar-benar menghayati nilai-nilai yang terkandung dalam suatu sistem politik yang ideal yang hendak dibangun. ${ }^{8}$

Pendidikan politik ialah suatu proses yang mengajarkan kepada masyarakat mengenai nilai-nilai, norma-norma, serta simbol-simbol politik melalui media berupa sekolah, pemerintah, dan juga partai politik. ${ }^{9}$ Hal ini perlu segera dilakukan pendidikan politik kepada pemilih tentang proses penyelenggaraan Pemilu serentak 2019 yang berbeda bila dibandingkan saat pelaksanaan Pemilu 2014.

Apalagi Komisi Pemilihan Umum mempunyai tagline Pemilih Berdaulat Negara Kuat untuk Pemilu 2019 yang dilaksanakan pada hari Rabu, 17 April 2019. Dari hasil penelitian, terdapat kekosongan hukum yang mewajibkan Komisi Pemilihan Umum untuk melakukan Sosialisasi, Pendidikan Pemilih, dan Partisipasi Masyarakat pada Pemilu 2019. Dalam proses Pemilihan Kepala Daerah terdapat aturan teknis yang mengatur adanya Sosialisasi, Pendidikan Pemilih, dan Partisipasi Masyarakat, namun tidak mencantumkan ancaman sanksi apabila tidak melaksanakan kegiatan dimaksud.

\section{KESIMPULAN}

Dari pembahasan diatas diperoleh kesimpulan bahwa data kependudukan yang diperoleh dari Pemerintah dan Pemerintah Daerah dilakukan pemutakhiran data pemilih yang dilakukan oleh KPU Kabupaten/Kota yang dibantu oleh Pantarlih, PPK, dan PPS. Pemutakhiran data pemilih ini dilakukan secara berjenjang mulai tingkat kelurahan, kecamatan, kabupaten/kota, provinsi hingga tingkat nasional. Pendidikan politik bagi pemilih menjelang pemilu serentak 2019 sangat penting untuk dilaksanakan, sebagai upaya mewujudkan Pemilih Berdaulat Negara Kuat. Namun belum ada petunjuk teknis Sosialisasi, Pendidikan Pemilih, dan Partisipasi Masyarakat pada Pemilu 2019 untuk pemilihan anggota DPR, anggota DPD, Presiden dan Wakil Presiden, dan anggota DPRD.

${ }^{8}$ Alfian, Pemikiran dan Perubahan Politik Indonesia, Liberty, Bandung, 1986 Bandung, hal. 235.

9 Muhadam Labolo dan Teguh Ilham, Partai Politik dan Sistem Pemilihan Umum di Indonesia : Teori, Konsep dan Isu Strategis, RajaGrafindo Persada, Jakarta, Cet. 2, 2017, hal. 20-21. 
Saran

Rekomendasi yang dihasilkan adalah dibuatnya aturan hukum tentang kewajiban dilaksanakannya pendidikan politik bagi pemilih menjelang Pemilu serentak 2019 sebagai upaya mewujudkan Pemilih Berdaulat Negara Kuat di Pemilu 2019 beserta ancaman sanksi bagi penyelenggara pemilu dalam suatu Undang-Undang.

Selain itu, masyarakat perlu didorong untuk terlibat aktif dalam melakukan update data kependudukannya kepada dinas terkait yang menangani administrasi kependudukan. Dalam penyelenggaran dan meningkatkan partisipasi masyarakat di Pemilu 2019 perlu dikeluarkan Peraturan KPU tentang Sosialisasi, Pendidikan Pemilih, dan Partisipasi Masyarakat pada Pemilu Serentak 2019.

Berdasarkan diskripsi, analis data, temuan penelitian, dan pembahasan maka dapat diambil kesimpulan bahwa Penerapan model inkuiri sosial dapat meningkatkan aktivitas dan hasil belajar siswa dalam pembelajaran IPS. Hal ini dibuktikan dengan meningkatnya kemampuan siswa dalam menjawab pertanyaan berbasis masalah, dengan prosentase keberhasilan 93,6\% diatas ketuntasan klasikal 85\%.

\section{DAFTAR PUSTAKA}

Alfian, 1986, Pemikiran dan Perubahan Politik Indonesia, Liberty, Bandung.

Cipto Handoyo, Hestu, 2003, Hukum Tata Negara, Kewarganegaraan Dan Hak Asasi Manusia, Universitas Atmajaya, Yogyakarta.

Gede Atmadja, I Dewa, dkk, 2015, Teori Konstitusi \& Konsep Negara Hukum, Setara Press, Malang.

Labolo, Muhadam dan Teguh Ilham, 2017, Partai Politik dan Sistem Pemilihan Umum di Indonesia : Teori, Konsep dan Isu Strategis, RajaGrafindo Persada, Cet. 2, Jakarta.

Mahfud, Moh. MD, 2011, Politik Hukum di Indonesia, Rajawali Pers, Ed. Revisi, Cet. 4, Jakarta.

Peraturan Komisi Pemilihan Umum Republik Indonesia Nomor 2 Tahun 2017 tentang Pemutakhiran Data dan Penyusunan Data Pemilih Dalam Pemilihan Gubernur dan Wakil Gubernur, Bupati dan Wakil Bupati, dan/atau Walikota dan Wakil Walikota.

Peraturan Komisi Pemilihan Umum Republik Indonesia Nomor 8 Tahun 2017 tentang Sosialisasi, Pendidikan Pemilih, dan Partisipasi Masyarakat Dalam Pemilihan Gubernur dan Wakil Gubernur, Bupati dan Wakil Bupati, dan/atau Walikota dan Wakil Walikota.

Undang-Undang Dasar Republik Indonesia 1945 Hasil Amandemen, 2006, Asa Mandiri, Jakarta. 
Undang-Undang Republik Indonesia Nomor 7 Tahun 2017 Tentang Pemilihan Umum, 2017, Citra Umbara, Bandung. 